\title{
Quantifying methane emissions from rice fields in the Taihu Lake region, China by coupling a detailed soil database with biogeochemical model
}

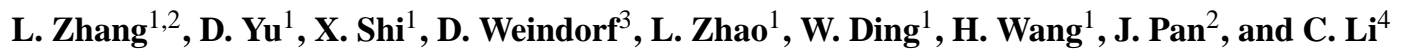 \\ ${ }^{1}$ State Key Laboratory of Soil and Sustainable Agriculture, Institute of Soil Science, Chinese Academy of Sciences, \\ Nanjing, China \\ ${ }^{2}$ College of Resources and Environmental Sciences, Nanjing Agricultural University, Nanjing, China \\ ${ }^{3}$ Louisiana State University AgCenter, Baton Rouge, Louisiana, USA \\ ${ }^{4}$ Institute for the Study of Earth, Oceans and Space, University of New Hampshire, Durham, USA
}

Received: 22 September 2008 - Published in Biogeosciences Discuss.: 11 December 2008

Revised: 28 April 2009 - Accepted: 28 April 2009 - Published: 6 May 2009

\begin{abstract}
As China has approximately $22 \%$ of the world's rice paddies, the regional quantification of $\mathrm{CH}_{4}$ emissions from these paddies is important in determining their contribution to the global greenhouse gas effect. This paper reports the use of a biogeochemical model (DeNitrification and DeComposition or DNDC) for quantifying $\mathrm{CH}_{4}$ emissions from rice fields in the Taihu Lake region of China. For this application, the DNDC model was linked to a 1:50000 soil database derived from 1107 paddy soil profiles compiled during the Second National Soil Survey of China in the 1980s-1990s. The simulated results showed that the 2.3 Mha of paddy rice fields in the Taihu Lake region emitted the equivalent of $5.7 \mathrm{TgC}$ from 1982-2000, with the average $\mathrm{CH}_{4}$ flux ranging from 114 to $138 \mathrm{~kg} \mathrm{Cha}^{-1} \mathrm{y}^{-1}$. As for soil subgroups, the highest emission rate $\left(660 \mathrm{~kg} \mathrm{Cha}^{-1} \mathrm{y}^{-1}\right)$ was linked to gleyed paddy soils accounting for about $4.4 \%$ of the total area of paddy soils. The lowest emission rate $\left(91 \mathrm{~kg} \mathrm{Cha}^{-1} \mathrm{y}^{-1}\right)$ was associated with degleyed paddy soils accounting for about $18 \%$ of the total area of paddy soils. The most common soil in the area was hydromorphic paddy soils, which accounted for about 53\% of the total area of paddy soils with a $\mathrm{CH}_{4}$ flux of $106 \mathrm{kgCha}^{-1} \mathrm{y}^{-1}$. On a regional basis, the annual averaged $\mathrm{CH}_{4}$ flux in the Taihu Lake plain soil region and alluvial plain soil region were higher than that in the low mountainous and hilly soil region and the polder soil region. The model simulation was conducted with two databases using polygons or counties as
\end{abstract}

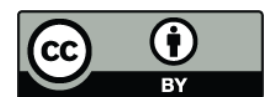

Correspondence to: $\mathrm{D}$. $\mathrm{Yu}$ (dshyu@issas.ac.cn) the basic units. The county-based database contained soil information coarser than the polygon system built based on the 1:50000 soil database. The modeled results with the two databases found similar spatial patterns of $\mathrm{CH}_{4}$ emissions in the Taihu Lake region. However, discrepancies exist between the results from the two methods. The total $\mathrm{CH}_{4}$ emissions generated from the polygon-based database is 2.6 times the minimum $\mathrm{CH}_{4}$ emissions generated from the county-based database, and is 0.98 times the maximum $\mathrm{CH}_{4}$ emissions generated from the county-based database. The average value of the relative deviation ranged from $-20 \%$ to $98 \%$ for most counties, which indicates that a more precise soil database is necessary to better simulate $\mathrm{CH}_{4}$ emissions from rice fields in the Taihu Lake region using the DNDC model.

\section{Introduction}

With economic development, environmental problems are becoming increasingly serious. The enhancement of the greenhouse effects is important aspect which has caused global concern. Methane $\left(\mathrm{CH}_{4}\right)$ is an important greenhouse gas and plays a large role in atmospheric processes. Since 1990, $\mathrm{CH}_{4}$ emissions are responsible for approximately $15 \%-20 \%$ of the greenhouse gas (GHG) emissions globally (IPCC, 1996). Presently, atmospheric $\mathrm{CH}_{4}$ concentration is $1774 \mathrm{ppb}$, and it is increasing rapidly at a rate of $1.0 \% \mathrm{yr}^{-1}$ (IPCC, 2007). Rice paddies have been identified as one of the major sources of atmospheric $\mathrm{CH}_{4}$, contributing about $12 \%$ to global $\mathrm{CH}_{4}$ emissions (Cicerone et al., 1988;

Published by Copernicus Publications on behalf of the European Geosciences Union. 
Lelieveld et al., 1993). China has approximately $22 \%$ of the world's rice paddies and $38 \%$ of the world's rice production, and $\mathrm{CH}_{4}$ emissions are responsible for approximately $28 \%$ of the total $\mathrm{CH}_{4}$ emission of the world's rice fields (Jiang et al., 2004; Wang et al., 1993). Over the past two decades, midseason drainage has been adopted throughout China as an alternative water management approach (Li et al., 2006). Field measurements in China indicate that midseason drainage significantly reduces $\mathrm{CH}_{4}$ emissions (Cai et al., 1999). Therefore, accurate estimates of $\mathrm{CH}_{4}$ emissions from the rice fields in China are vitally important for a comprehensive understanding of global GHG dynamics.

Recently, scientists have used models to estimate $\mathrm{CH}_{4}$ emissions from cropping systems (Cao et al., 1995a, b, 1996, 1998; Huang et al., 1998; Matthews et al., 2000a, b). The DeNitrification-DeComposition (DNDC) model developed by $\mathrm{Li}$ et al. is a process-based model focused on trace gas emissions from agroecosystems (Li et al., 1992a, b, 1994). Using this model, environmental impacts on $\mathrm{CH}_{4}$ emissions such as climate change, land-use change, and agricultural activities including alternative farming management practices, can be assessed in a comprehensive way. Presently, the DNDC model has demonstrated good performance through its long-term applications in North America, Europe, Asia and Oceania. For instance, Li et al. (2000) tested the model against observed $\mathrm{CH}_{4}$ emissions from a rice field in Beaumont, Texas, USA. The simulated and measured relative deviation of $\mathrm{CH}_{4}$ emissions was $5.4 \%$, which demonstrated that the DNDC model could accurately simulate $\mathrm{CH}_{4}$ emissions. Jagadeesh et al. (2006) simulated $\mathrm{CH}_{4}$ and $\mathrm{N}_{2} \mathrm{O}$ emissions from rice fields at different locations in India using the DNDC model and found that most discrepancies between simulated and observed seasonal fluxes were less than $20 \%$ of the field estimate of the seasonal flux.

The DNDC model has also been utilized to upscaling $\mathrm{CH}_{4}$ emissions from local site to regional scales. So far, most of the DNDC modeling conducted at regional scale has used counties as the basic geographic unit. However, regional estimates of $\mathrm{CH}_{4}$ fluxes cannot be derived simply from the extension of results from field-plot measurement of $\mathrm{CH}_{4}$ fluxes because of the spatial variations in climate, soil, and management practices (Jagadeesh et al., 2006). As such, county scale model simulations can have great uncertainties as soil properties are averaged for each county, largely ignoring the nonlinear impacts of soil heterogeneity within a county (Pathak et al., 2005; Li et al., 2004; Cai et al., 2003).

For the rice-dominated Taihu Lake Region, we shifted the regional database linked to the DNDC model from a countybased to a grid-basd system which was built upon a new soil map that was recently developed in China. The 1:50000 soil map was derived from 1107 paddy soil profiles summarized in the Second National Soil Survey of China in the 1980s1990s. By linking the detailed soil database to DNDC model, we attempted to improve the performance of the model. The goals of this study were to (1) estimate the inter-annual vari-

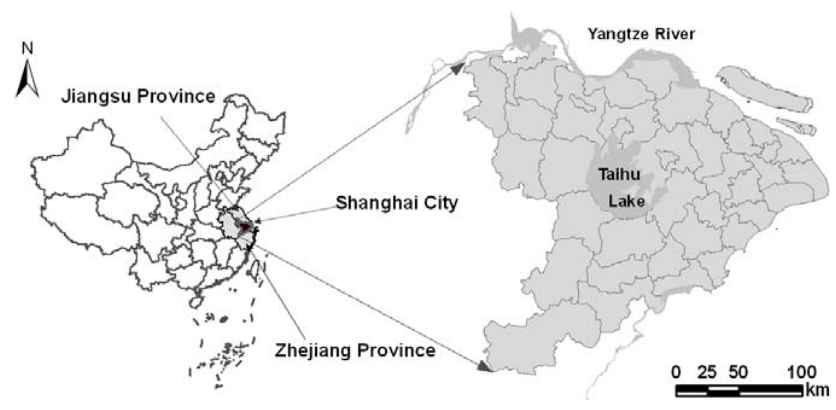

Fig. 1. Geographical location of the study area in China.

ation in $\mathrm{CH}_{4}$ emissions from rice paddy fields in the Taihu Lake region of China from 1982 to 2000; (2) display the $\mathrm{CH}_{4}$ emissions patterns in different paddy soil subgroups as well as different soil sub-regions; and (3) compare $\mathrm{CH}_{4}$ emissions modeled with polygon- and county-based databases.

\section{Materials and methods}

\subsection{Study area}

The Taihu Lake region $\left(118^{\circ} 50^{\prime}-121^{\circ} 54^{\prime} \mathrm{E}, \quad 29^{\circ} 56^{\prime}-\right.$ $32^{\circ} 16^{\prime} \mathrm{N}$ ), an area of intensive rice cultivation, is located in the middle and lower reaches of the Yangtze River paddy soil region of China, includes the entire Shanghai City administrative area and a part of Jiangsu and Zhejiang provinces, and covers a total area of $36500 \mathrm{~km}^{2}$ (Fig. 1) (Li, 1992). It mainly consists of plains formed on deltas with numerous rivers and lakes within the region. The climate is warm and moist with plenty of sunshine and a long growing season. Annual rainfall is $1100-1400 \mathrm{~mm}$, and with a mean temperature of $16^{\circ}$, and average annual sunshine of $1870-2225 \mathrm{~h}$. The frost-free period is over 230 days. The study area is one of the oldest agricultural regions in China, with a history of rice cultivation for several centuries. Approximately 66\% of the total land area is covered with paddy soils (Xu et al., 1980).

The paddy soils are derived mostly from loess, alluvium and lacustrine deposits and are classified in the following subgroups according to US Soil Taxonomy (ST) or the World Reference Base Soil Taxonomy (WRB) (Soil Survey Staff, 1994; Shi et al., 2006): Hydromorphic (Typic Epiaquepts or Hydragric Anthrosols), Submergenic (Typic Endoaquepts or Hydragric Anthrosols), Bleached (Typic Epiaquepts or Hydragric Anthrosols), Gleyed (Typic Endoaquepts or Gleyichydragric Anthrosols), Percogenic (Typic Epiaquepts or Hydragric Anthrosols), and Degleyed (Typic Endoaquepts or Gleyic-hydragric Anthrosols). Most of the croplands are managed with rice and winter wheat rotation systems. Rice is planted in June and harvested in October and wheat is planted in November and harvested in May. 


\subsection{Description of the DNDC model}

The DNDC (DeNitrification \& DeComposition) model, under development at the University of New Hampshire since 1992, is a process-orientated simulation tool for soil carbon and nitrogen biogeochemistry cycles (Li et al., 1992 a, b, 1994, 1996). Presently, the DNDC model is one of the more widely accepted biogeochemical models in the world $(\mathrm{Li}$, 2000, 2007). The model contains six interacting sub-models which describe the generation, decomposition, and transformation of organic matter, and outputs the dynamics components of SOC and greenhouse gases fluxes.

The six sub-models include: (1) soil climate sub-models, which use soil physical properties, air temperature, and precipitation data to calculate soil temperature, moisture and redox potential (Eh) profiles and soil water fluxes through time. The results of the calculation are then fed to the other submodels; (2) a nitrification sub-model; (3) a denitrification sub-model, which calculates hourly denitrification rates and $\mathrm{N}_{2} \mathrm{O}, \mathrm{NO}$ and $\mathrm{N}_{2}$ production during periods when the soil Eh decreases due to rainfall, irrigation, flooding or soil freezing; (4) a sub-model simulating the decomposition of SOC pools and $\mathrm{CO}_{2}$ production through soil microbial respiration; (5) a plant growth sub-model, which calculates daily root respiration, water and $\mathrm{N}$ uptake by plants, and plant growth; and (6) a fermentation sub-model, which calculates daily methane $\left(\mathrm{CH}_{4}\right)$ production and oxidation.

The DNDC model can simulate $\mathrm{C}$ and $\mathrm{N}$ biogeochemical cycles in paddy rice ecosystems, whereby the model has been implemented by adding a series of anaerobic processes (Li et al., 2002, 2004; Li, 2007; Cai et al., 2003). Paddy soil is characterized by frequent changes between saturated and unsaturated conditions driven by water management. During changes in soil water content, the soil Eh is subject to substantial changes between +600 and $-300 \mathrm{mV}$.

The DNDC model allocates substrates (e.g., $\mathrm{DOC}, \mathrm{NO}_{3}^{-}$, $\mathrm{NH}_{4}^{+}$etc.) to reductive reactions (e.g., denitrification, methanogenesis) and oxidative reactions (e.g., nitrification, methanotrophy) based on the relative fractional volumes of the oxidizing and reducing zones, and the potential oxidation and reduction reactions determined by $\mathrm{Eh}$ and $\mathrm{pH}$ (Yu et al., 2001, 2004; Li, 2007). By tracking the formation and deflation of a series of Eh volume fractions driven by depletions of $\mathrm{O}_{2}, \mathrm{NO}_{3}^{-}, \mathrm{Mn}^{4+}, \mathrm{Fe}^{3+}$, and $\mathrm{SO}_{4}^{2-}$ consecutively, the DNDC model estimates soil Eh dynamics as well as rates of reductive/oxidative reactions, which produce and consume $\mathrm{CH}_{4}$ or $\mathrm{N}_{2} \mathrm{O}$ in the soil. This tracking links the soil water regime to trace gas emissions for rice paddy ecosystems. Temporally, the DNDC model predicts daily $\mathrm{CH}_{4}$ and $\mathrm{N}_{2} \mathrm{O}$ fluxes from rice fields during periods of extended flooding or shifts between flooded and drained states through the growing and fallow seasons.

\subsection{Database development}

A major challenge for using an ecosystem model at a regional scale is to assemble adequate datasets required to initialize and run the model. DNDC modeling of $\mathrm{CH}_{4}$ emissions from rice paddy fields requires data describing the soil properties, daily weather, cropping systems, and agricultural management practices.

In this study, two types of spatial soil databases, polygonbased and county-based, were used to support the DNDC regional simulations. The polygon-based soil database contained 52034 polygons of paddy soils representing 1107 paddy soil profiles extracted from the latest national soil map (1:50 000), which was compiled using the Pedological Knowledge Based (PKB) method (Shi et al., 2004). The soil dataset covered 37 counties in the Taihu Lake region. The mapping units are based on the soil types as defined in $\mathrm{Ge}$ netic Soil Classification of China (GSCC). The soil dataset consisted of many soil attribute fields, including profile code, soil name (in GSCC), profile thickness, bulk density, organic matter content, texture, $\mathrm{pH}$, etc. The county-based soil database was built from the default method developed for DNDC, in which the maximum and minimum values of soil texture, $\mathrm{pH}$, bulk density, and organic carbon content were recorded for each county. The maximum and minimum values of the soil parameters were also induced from the 1:50000 soil database with relatively coarse source data. During the regional runs with the county-based database, the DNDC produced two $\mathrm{CH}_{4}$ fluxes resulting from two runs with the maximum and minimum soil values, respectively. The two flux values formed a range to define the uncertainty induced from upscaling each county (see detail in Li et al., 2004). For comparison in this study, both the polygon-based and county-based soil databases were run concurrently so the DNDC model could generalize regional $\mathrm{CH}_{4}$ emissions for the Taihu Lake region.

The crop dataset included physiological data of summer rice and winter wheat. The agricultural management dataset included sowing acreages, nitrogen fertilizer application rates, livestock, planting and harvest dates, and agricultural population at the county level from 1982 to 2000 (from the Institute of Geographic Sciences and Natural Resources Research, Chinese Academy of Sciences). The climate dataset included daily weather data (precipitation, maximum and minimum air temperature) from 1982-2000, which was acquired from 13 weather stations in the Taihu Lake region (from Institute of Atmospheric Physics, Chinese Academy of Sciences). Each of the counties in the simulation was assigned to a weather station nearest to the evaluated county.

Farming management scenarios were compiled based on the assumptions as follows (Tang et al., 2006; Qiu et al., 2004): (1) Nitrogen fertilizer consisted of $40 \%$ urea, $40 \%$ $\mathrm{NH}_{4} \mathrm{HCO}_{3}$, and $20 \% \mathrm{NH}_{4} \mathrm{H}_{2} \mathrm{PO}_{3}$; (2) $15 \%$ of aboveground crop residue was returned to the soil; (3) $20 \%$ livestock 
Table 1. The $\mathrm{CH}_{4}$ emission from rice fields of the Tai-Lake region in China.

\begin{tabular}{|c|c|c|c|c|}
\hline Author & Location & year & Treatment and fertilizing amount & Emission \\
\hline \multirow{4}{*}{ Cai et al. (1994) } & \multirow{4}{*}{ 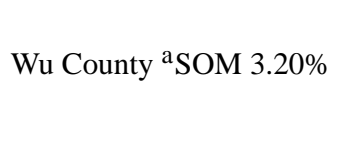 } & \multirow{4}{*}{ 1992-1993 } & $\mathrm{kg} \mathrm{Nha}^{-1} \mathrm{y}^{-1}$ & $\mathrm{kgCha}^{-1} \mathrm{y}^{-1}$ \\
\hline & & & no fertilizer & 122.3 \\
\hline & & & ammonium sulfate 223 & 73.7 \\
\hline & & & ammonium sulfate $223+$ manure & 135.0 \\
\hline \multirow{5}{*}{ Cai et al., 1995} & \multirow{5}{*}{${ }^{\mathrm{b} J A S S}$ SOM $1.85 \%$} & \multirow{5}{*}{1994} & ammonium sulfate $223+$ nitrification inhibitor & 99.0 \\
\hline & & & ammonium sulfate 223 continuous flooding & 143.3 \\
\hline & & & contrast & 59.3 \\
\hline & & & ammonium sulfate 100 & 34.5 \\
\hline & & & ammonium sulfate 300 & 24.0 \\
\hline \multirow{5}{*}{ Li et al., 1993} & \multirow{5}{*}{ Jiangning SOM $2.29 \%$} & \multirow{5}{*}{ 1990-1992 } & urea 100 & 55.5 \\
\hline & & & urea 300 & 51.0 \\
\hline & & & manure+urea 100 & 195.0 \\
\hline & & & manure & 171.0 \\
\hline & & & ammonium sulfate 140 & 47.3 \\
\hline \multirow{3}{*}{ Xiong et al. (1999) } & \multirow{3}{*}{ Wu County SOM 3.5\% } & \multirow{3}{*}{ 1994-1996 } & manure+urea 100 half of dry farming & 119.3 \\
\hline & & & urea 191 & 82.5 \\
\hline & & & ammonium hydrogen carbonate 191 & 52.5 \\
\hline
\end{tabular}

a SOM: Soil Organic Matter;

b JASS: Jiangsu Academy for Agriculture Science.

wastes and $10 \%$ human wastes were added as manure to the soil; (4) One midseason drainage and shallow flooding were applied to summer rice; and (5) For the rice-wheat rotation, tillage was conducted twice before 1990 at $20 \mathrm{~cm}$ for rice and $10 \mathrm{~cm}$ for wheat on the planting dates; No-till was applied for wheat after 1990.

\section{Results and discussion}

\subsection{Model validation}

At present, the DNDC model has been tested against several $\mathrm{CH}_{4}$ flux datasets from wetland rice sites in the United States, Italy, China, Tailand, and Japan (Li et al., 2002; Cai et al., 2003). For sites in East Asia, simulated seasonal $\mathrm{CH}_{4}$ emissions from paddy soils were in good agreement with field studies $\left(r^{2}=0.96\right.$, regression slope $=1.1, n=23$ ) (Cai et al., 2003). Results showed that if the site soil characteristics, fertilization rate, fertilization type, crop and water management were well described, simulated fluxes were similar to observation (Fig. 2) (Zheng et al., 1997).

Previous field measurement of $\mathrm{CH}_{4}$ emissions from the rice fields in the Taihu Lake region of China ranged from 20 to $200 \mathrm{~kg} \mathrm{Cha}^{-1} \mathrm{y}^{-1}$ (Table 1) (Wang et al., 2001). In our study, DNDC-modeled $\mathrm{CH}_{4}$ emissions from the majority paddy soils were in the range of 20 to $200 \mathrm{~kg} \mathrm{Cha}^{-1} \mathrm{y}^{-1}$ (Fig. 3), indicating that the modeled results are consistent with observations for the Taihu Lake region. Table 1 shows that plots with no-fertilizer application yielded higher $\mathrm{CH}_{4}$ fluxes than those receiving only mineral fertilizer nitrogen

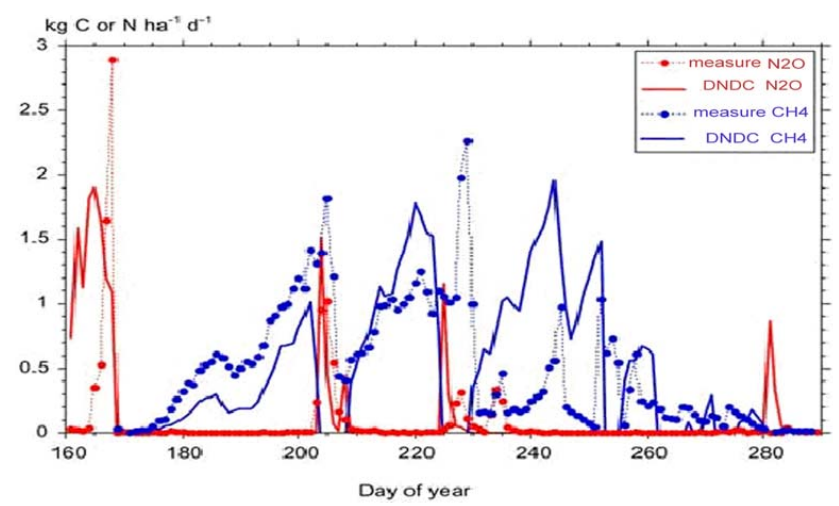

Fig. 2. Comparison between observed and DNDC-modeled $\mathrm{CH}_{4}$ and $\mathrm{N}_{2} \mathrm{O}$ fluxes from a paddy rice field applied with midseason drainage in Wu County, the Taihu Lake region, China, in 1995.

(Cai et al., 1994). This was consistent with the general belief that alternating flooding and drainage (treatment of "ammonium sulfate 223") should be beneficial in reducing $\mathrm{CH}_{4}$ emissions from rice paddy soils ( $\mathrm{Li}$ et al., 2002). Under the same water regime conditions, addition of $\left(\mathrm{NH}_{4}\right)_{2} \mathrm{SO}_{4}$ depressed $\mathrm{CH}_{4}$ fluxes from rice fields, and the depressing effect of $\left(\mathrm{NH}_{4}\right)_{2} \mathrm{SO}_{4}$ on $\mathrm{CH}_{4}$ fluxes seemed to be alleviated by the addition of a nitrification inhibitor.

The simulated $\mathrm{CH}_{4}$ emission using the DNDC model closely reflected field observations in Nanjing, Jiangning, Wu County, Hangzhou, Jurong, and Suzhou of the Taihu Lake region (Table 2) (Wang et al., 2001; Cai 


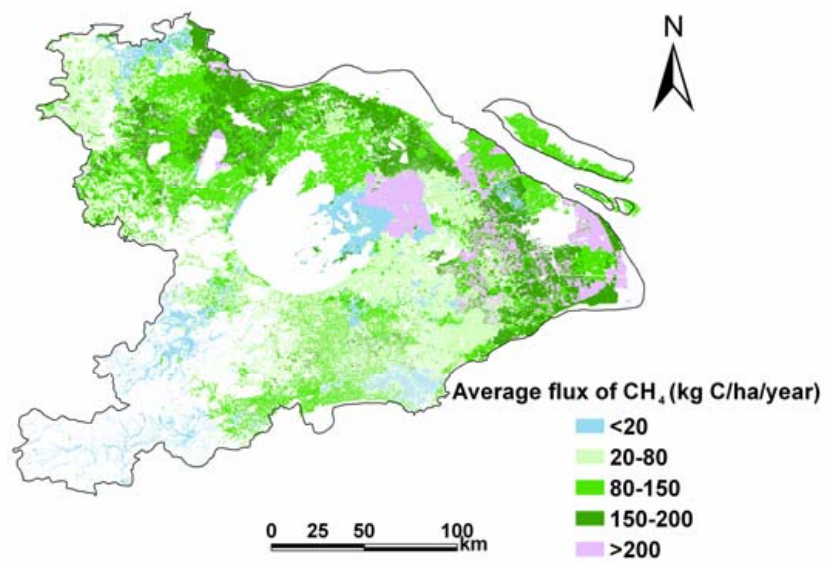

Fig. 3. Distribution of the average $\mathrm{CH}_{4}-\mathrm{C}$ flux from 1982 to 2000 in the Taihu Lake region, China.

et al., 2003). Total $\mathrm{CH}_{4}$ emissions ranged from 14 to $180 \mathrm{~kg} \mathrm{Cha}^{-1} \mathrm{y}^{-1}$, while simulated emissions ranged from 15 to $198 \mathrm{~kg} \mathrm{Cha}^{-1} \mathrm{y}^{-1}$. The difference between the observed and simulated emissions in all sites ranged from -12 to $51 \mathrm{~kg} \mathrm{Cha}^{-1} \mathrm{y}^{-1}$. The highest percentage of relative deviation was found at the Nanjing site while the lowest was recorded at the Suzhou site. Most discrepancies between the simulated and observed yearly fluxes were less than $10 \%$, which showed that the $\mathrm{CH}_{4}$ emissions from paddy soil in the Taihu Lake region were well simulated by the DNDC model.

\subsection{Inter-annual variation in $\mathrm{CH}_{4}$ emissions in the Taihu Lake region}

Based on simulated results, the $2.3 \mathrm{M}$ ha of paddy soils cultivated with summer rice and winter wheat in the Taihu Lake region emitted the equivalent of $5.7 \mathrm{Tg} \mathrm{C}$ from $\mathrm{CH}_{4}$ from 1982-2000. The average $\mathrm{CH}_{4}$ flux ranged from $114 \mathrm{~kg} \mathrm{Cha}^{-1} \mathrm{y}^{-1}$ to $138 \mathrm{kgCha}^{-1} \mathrm{y}^{-1}$. However, the modeled annual $\mathrm{CH}_{4}$ emission was highly variable from year to year (Fig. 4). From 1982-1985, the $\mathrm{CH}_{4}$ emissions of the entire area were very low, accounting for $19 \%$ of the total $\mathrm{CH}_{4}$ emissions. This was mainly caused by the low input of chemical fertilizer and manure. The chemical fertilizer application rate ranged from $180 \mathrm{~kg} \mathrm{Nha}^{-1} \mathrm{yr}^{-1}$ to $210 \mathrm{~kg} \mathrm{Nha}^{-1} \mathrm{yr}^{-1}$ and the manure rate ranged from $230 \mathrm{~kg} \mathrm{Cha}^{-1} \mathrm{yr}^{-1}$ to $240 \mathrm{~kg} \mathrm{Cha}^{-1} \mathrm{yr}^{-1}$. After that (from 1986 to 1992), the application rates of fertilizer tended to increase. Chemical fertilizers increased from $260 \mathrm{~kg} \mathrm{Nha}^{-1} \mathrm{yr}^{-1}$ to $400 \mathrm{~kg} \mathrm{Nha}^{-1} \mathrm{yr}^{-1}$ and manure went up from $230 \mathrm{~kg} \mathrm{Nha}^{-1} \mathrm{yr}^{-1}$ to $280 \mathrm{~kg} \mathrm{Nha}^{-1} \mathrm{yr}^{-1}$. The increase in livestock number provided more manure, which in turn enhanced substrates for methanogenesis (Sass et al., 1991; Zheng et al., 1999; Sun et al., 2007). While additional fertilizer application could lead to an increase in $\mathrm{CH}_{4}$ emissions due to an increase in rice productivity and biomass, a decrease due to soil Eh value induced induced by fertilizers

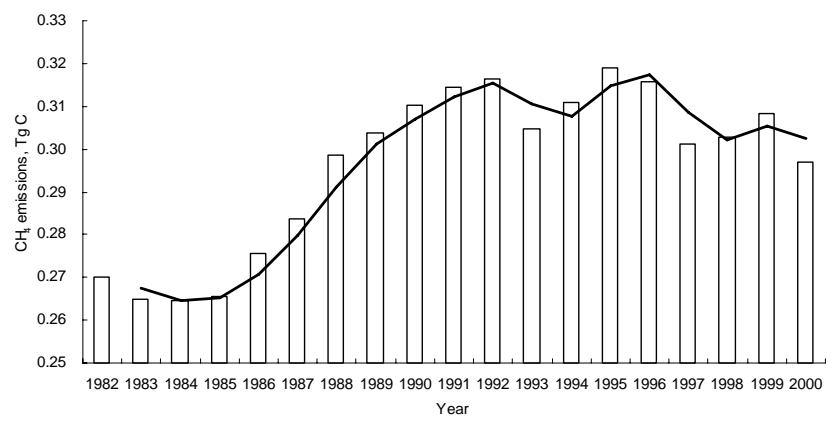

Fig. 4. Distribution of $\mathrm{CH}_{4}$ emission from 1982 to 2000 in the Taihu Lake region, China.

such as ammonium sulfate is also plausible (Lindau et al., 1990; Denier van der Gon and Neue, 1994; Wassmann et al., 1994; Yao and Chen, 1994; Dunfield et al., 1995). The seven years from 1986 to 1992 accounted for 37\% of the total $\mathrm{CH}_{4}$ emissions. However, the increasing rate of modeled $\mathrm{CH}_{4}$ emissions decreased from 1993 to 2000 . Agricultural statistics show that the amount of synthetic fertilizers used in the region has decreased since 1993 (from the Institute of Geographic Sciences and Natural Resources Research, Chinese Academy of Sciences).

\section{3 $\mathrm{CH}_{4}$ emission pattern in different paddy soil sub- groups in the Taihu Lake region}

The hydromorphic subgroup is the most prominent paddy soil type in the Taihu Lake region, accounting for 53\% of the total paddy soil area (Fig. 5a). This group contains a high organic carbon content $\left(15 \mathrm{~g} \mathrm{~kg}^{-1}\right)$ and total nitrogen $\left(2.0 \mathrm{~g} \mathrm{~kg}^{-1}\right)$ making it favorable for $\mathrm{CH}_{4}$ production by providing more substrates (soluble $\mathrm{C}$, ammonium, and nitrate) (Zheng et al., 1999; Yao et al., 1999).The modeled average $\mathrm{CH}_{4}$ flux was $106 \mathrm{~kg} \mathrm{Cha}^{-1} \mathrm{y}^{-1}$ (Fig. 5a, b). In the Taihu Lake region, the total $\mathrm{CH}_{4}$ emissions from this subgroup were equivalent to $2.5 \mathrm{TgC}$, accounting for $44 \%$ of the total $\mathrm{CH}_{4}$ emissions from the region.

The degleyed and percogenic subgroups cover $18 \%$ and $16 \%$ of the total paddy soil area in the region, respectively. The modeled $\mathrm{CH}_{4}$ from the degleyed and percogenic subgroups were equivalent to 0.71 and $0.83 \mathrm{Tg} \mathrm{C}$, and accounted for $12 \%$ and $15 \%$ of the regional $\mathrm{CH}_{4}$ emissions, respectively. The $\mathrm{CH}_{4}$ emission rate from the percogenic subgroup was higher than the degleyed subgroup. The main reasons were that the $\mathrm{pH}$ value of the former was close to neutral (6.9), and the clay content was only $22 \%$. The latter was weakly acidic (6.5), and had a clay content of $30 \%$. Some studies show that the optimum $\mathrm{pH}$ range for $\mathrm{CH}_{4}$ production is 6.8-7.2 (Pacey et al., 1986), and soil texture has also been documented to affect $\mathrm{CH}_{4}$ emissions from rice fields, increasing emissions with decreasing clay content (Cai et al., 1999). 
Table 2. Comparison between observed and DNDC-modeled $\mathrm{CH}_{4}$ fluxes from rice fields in the Taihu Lake region, China.

\begin{tabular}{lcccc}
\hline Location & Year & Observed $\left(\mathrm{kg} \mathrm{Cha}^{-1} \mathrm{y}^{-1}\right)$ & Simulated $\left(\mathrm{kgCha}^{-1} \mathrm{y}^{-1}\right)$ & Relative deviation (\%) \\
\hline Nanjing & 1994 & $24.0-55.5(39.8)$ & $35.3-51.8(43.5)$ & 9.4 \\
Jiangning & $1990-1992$ & $47.3-195.0(121.1)$ & $75.0-144.8(109.9)$ & -9.3 \\
Wu County & $1992-1996$ & $52.5-143.3(97.9)$ & $53.3-93.0(73.1)$ & -25.2 \\
Hangzhou & $1987-1989$ & $120.0-240.0(180.0)$ & $148.5-246.8(197.6)$ & 9.8 \\
Nanjing & 1994 & 57.8 & 41.3 & -28.6 \\
Jurong & 1995 & 14.3 & 14.7 & 3.2 \\
Jurong & 1997 & 49.5 & 55.0 & 11.1 \\
Suzhou & 1993 & 122.3 & 122.9 & 0.6 \\
Suzhou & 1993 & 143.3 & 151.8 & 9.8 \\
\hline
\end{tabular}
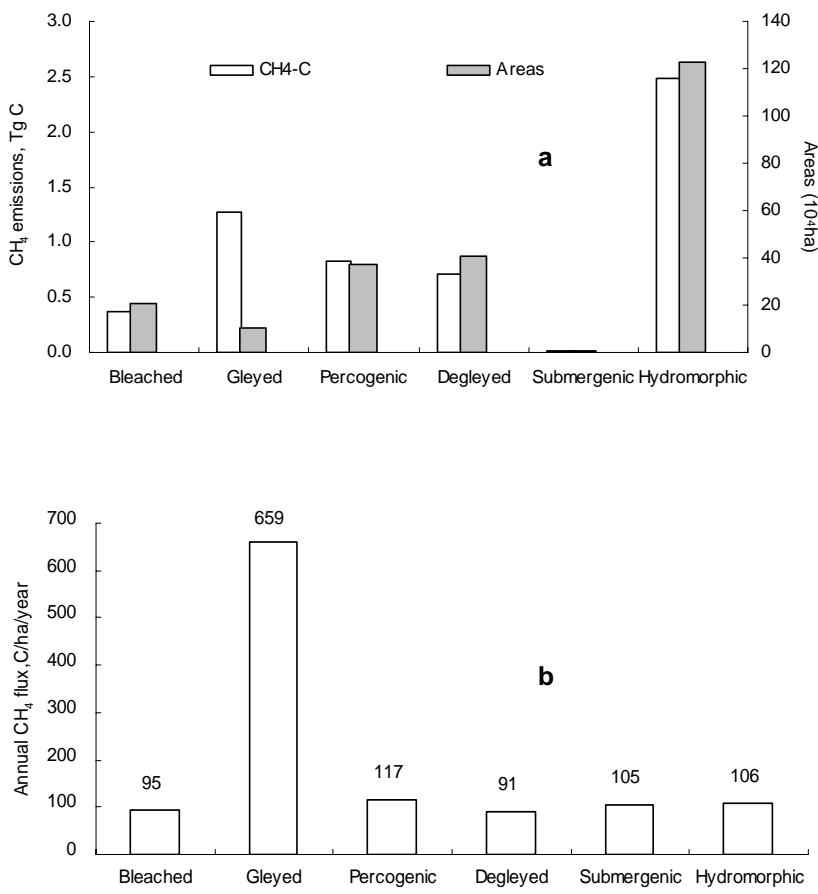

Fig. 5. (a) Comparison between areas and total $\mathrm{CH}_{4}$ emissions in various paddy soil subgroups of the Taihu Lake region, China. (b) Comparison of the average $\mathrm{CH}_{4}$ flux per year in various paddy soil subgroups of the Taihu Lake region, China.

In the Taihu Lake region, submergenic soils support $0.0073 \mathrm{Mha}$ of rice fields with an emission rate of $105 \mathrm{~kg} \mathrm{Cha}^{-1} \mathrm{y}^{-1}$. Although this subgroup has a neutral $\mathrm{pH}$ value $(6.8)$ and a low clay content $(15 \%)$, the organic carbon content was only $10 \mathrm{~g} \mathrm{~kg}^{-1}$, leading to moderate $\mathrm{CH}_{4}$ emissions (Fig. 5a, b). The areas dominated by gleyed and bleached soil account for 4.4 and $8.8 \%$ of the regional paddy soil area, with average $\mathrm{CH}_{4}$ fluxes of 660 and $95 \mathrm{~kg} \mathrm{Cha}^{-1} \mathrm{y}^{-1}$, respectively. The $\mathrm{CH}_{4}$ emission rate from the gleyed subgroup was much higher than other soil subgroups due to continuous flooding and a high organic carbon

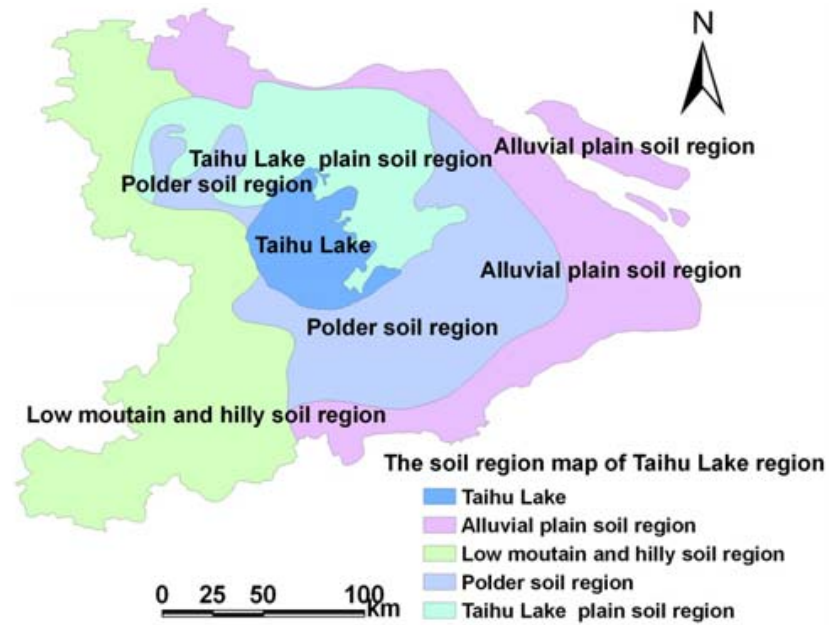

Fig. 6. The paddy soil region map of the Taihu Lake region, China.

content $\left(25 \mathrm{~g} \mathrm{~kg}^{-1}\right)$ (Yagi and Minami, 1990; Wang et al., 1993). The $\mathrm{CH}_{4}$ emission rate from the bleached subgroup was low due to low organic carbon content $\left(10 \mathrm{~g} \mathrm{~kg}^{-1}\right)$.

\section{4 $\mathrm{CH}_{4}$ emission patterns in different paddy soil sub- regions in the Taihu Lake region}

The Taihu Lake region can be divided into four sub-regions based on landscape characteristics: rolling hills, plains around the lake, plains along the river, and polders (Xu et al., 1980) (Fig. 6).

The rolling hills and low mountains sub-region was distributed in the western and northern extents with paddy fields of $0.39 \mathrm{Mha}$. Soils in this sub-region are weakly acidic (6.0), have low soil organic carbon content $\left(13 \mathrm{~g} \mathrm{~kg}^{-1}\right)$ and are well drained (Ma et al., 1999; Rashid et al., 2008). The modeled average $\mathrm{CH}_{4}$ flux rate for the region was equivalent to $68 \mathrm{~kg} \mathrm{Cha}^{-1} \mathrm{y}^{-1}$.

The plain around the lake sub-region exists as an arc shape and spreads northward and eastward from the center. The $0.59 \mathrm{Mha}$ of rice fields have high soil organic 

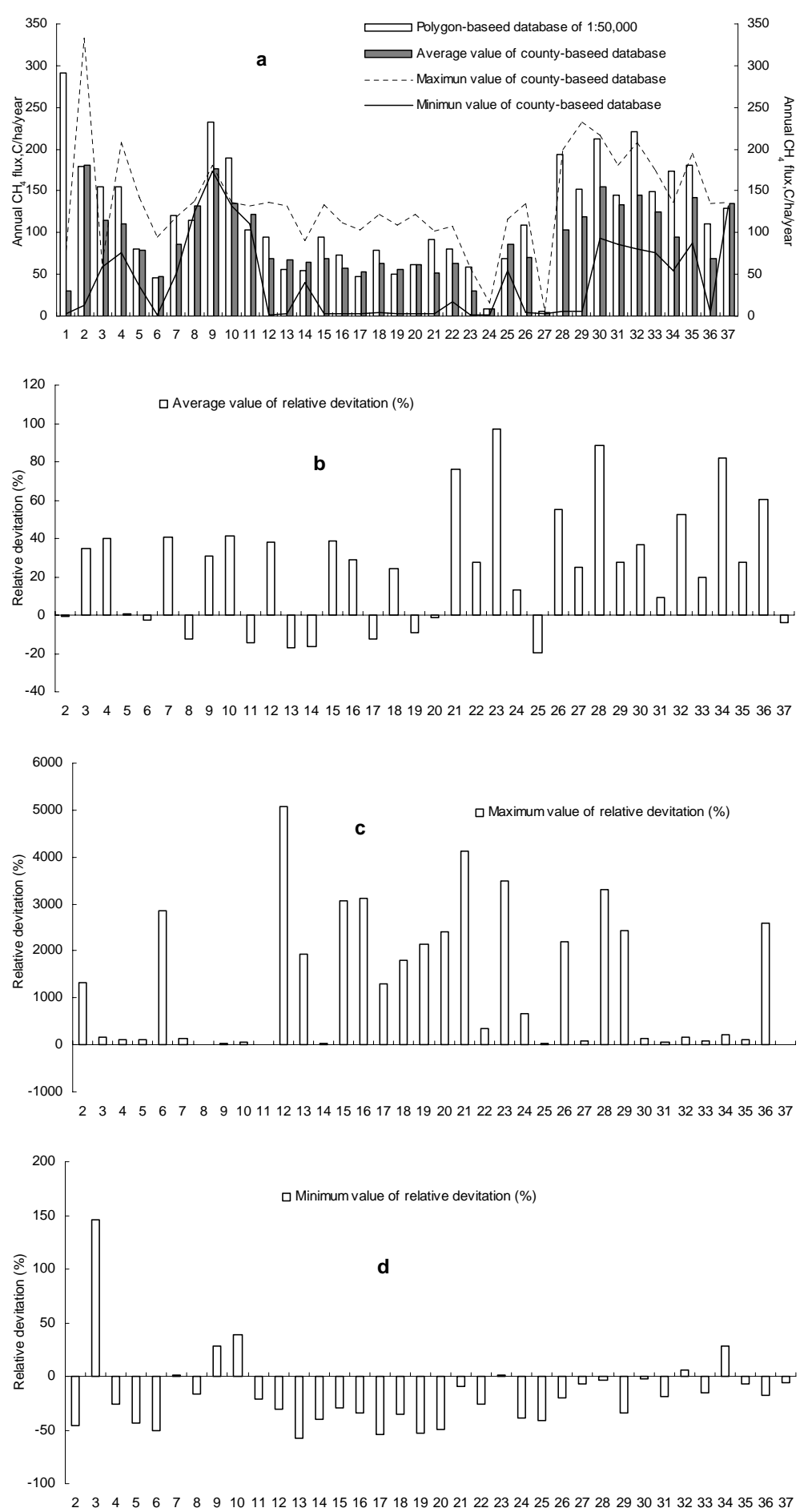

Fig. 7. (a) Comparison of the average $\mathrm{CH}_{4}$ flux modeled with the county- and polygon-based database for the Taihu Lake region, China; and (b, $\mathbf{c}$ and $\mathbf{d}$ ) average (maximum or minimum) value of the relative deviation of the average $\mathrm{CH}_{4}$ flux modeled with the polygon-based database by county level as a baseline for the Taihu Lake region, China. (1. Wu County; 2. Zhangjiagang; 3. Changshu; 4. Taicang; 5. Kunshan; 6. Wujiang; 7. Wuxi; 8. Jiangyin; 9. Wujin; 10. Jintan; 11. Liyang; 12. Yixing; 13. Dantu; 14. Jurong; 15. Danyang; 16. Jiaxing; 17. Jiashan; 18. Pinghu; 19. Haiyan; 20. Haining; 21. Tongxiang; 22. Huzhou; 23. Changxing; 24. Anji; 25. Deqing; 26. Yuhang; 27. Linan; 28. Minhang; 29. Jiading; 30. Chuansha; 31. Nanhui; 32. Qingpu; 33. Songjiang; 34. Jinshan; 35. Fengxian; 36. Baoshan; 37. Chongming.) 
carbon $\left(16 \mathrm{~g} \mathrm{~kg}^{-1}\right)$ and large amounts of fertilizers applied $\left(302 \mathrm{~N} \mathrm{ha}^{-1} \mathrm{yr}^{-1}\right)$. Moreover, gleyed soils cover an extensive area in this sub-region. So, the modeled average $\mathrm{CH}_{4}$ flux was equivalent to $173 \mathrm{~kg} \mathrm{Cha}^{-1} \mathrm{y}^{-1}$.

The alluvia plains along the river sub-region contains about $0.64 \mathrm{M}$ ha of rice fields. The soil organic carbon is $23 \mathrm{~g} \mathrm{~kg}^{-1}$ and the soil $\mathrm{pH}$ is 7.3. A reaction range of $6.8-$ 7.2 is favorable for methane production (Pacey et al., 1986). Moreover, fertilizer application ( $370 \mathrm{Nha}^{-1} \mathrm{yr}^{-1}$ ) was high in this sub-region. The modeled average $\mathrm{CH}_{4}$ flux was equivalent to $133 \mathrm{~kg} \mathrm{Cha}^{-1} \mathrm{y}^{-1}$.

The polder sub-region is low in elevation, and contains 0.69 Mha of rice fields. Soils in this sub-region were mostly weakly acidic (6.5), and clay contents reach $\sim 30 \%$. The modeled average $\mathrm{CH}_{4}$ flux was equivalent to $118 \mathrm{~kg} \mathrm{Cha}^{-1} \mathrm{y}^{-1}$.

\subsection{Comparison of $\mathrm{CH}_{4}$ emissions modeled with polygon- and county-based databases in the Taihu Lake region}

According to the default method for regional simulations with the DNDC model, counties are used as the basic simulation unit. The county-based database usually requires relatively less soil data. However, when the DNDC model is used for a region with high heterogeneity in soil properties, the method produces higher uncertainty due to limited spatially differentiated soil information (Pathak et al., 2005; Cai et al., 2003; Li et al., 2004; Rüth et al., 2008). The study carried out for the Taihu Lake region has provided a chance to test the uncertainty as there is detailed soil information available for the region. The polygon-based soil database contains 52034 polygons. By contrast, only 37 counties are found in the county-based database. However, DNDC model runs with the polygon-based database produced a single $\mathrm{CH}_{4}$ flux for each polygon while runs with the county-based database produced a range of $\mathrm{CH}_{4}$ fluxes to define the uncertainty. The results simulated by DNDC with the two types of databases were compared to assess the advantages of using the detailed, polygon-based soil dataset.

Figure $7 \mathrm{a}$ shows the average $\mathrm{CH}_{4}$ flux modeled with the county- and polygon-based databases for the Taihu Lake region. In the figure, the average $\mathrm{CH}_{4}$ fluxes modeled with the county-based database are expressed with ranges defined by the minimum and maximum $\mathrm{CH}_{4}$ fluxes. The average $\mathrm{CH}_{4}$ flux modeled with the polygon-based database is expressed with single values. Results from the two methods demonstrate the spatial patterns of $\mathrm{CH}_{4}$ emissions across the 37 simulated counties. Most of the polygon-based $\mathrm{CH}_{4}$ fluxes are located within the ranges produced by the county-based method. However, discrepancies exist between results from the two methods. For the Taihu Lake region, the total $\mathrm{CH}_{4}$ emissions modeled with the county-based database ranged from 2.2 to $5.8 \mathrm{TgC}$; and the total $\mathrm{CH}_{4}$ emissions modeled with the polygon-based database is equivalent to 5.7.
The total $\mathrm{CH}_{4}$ emissions generated from the polygon-based database are 2.6 times the minimum $\mathrm{CH}_{4}$ emissions generated from the county-based database, and 0.98 times the maximum $\mathrm{CH}_{4}$ emissions generated from the county-based database. The relative deviation of maximum and minimum is $60 \%$ and $-2.0 \%$ for the entire region, respectively.

For most of the simulated counties, there are large differences in the average $\mathrm{CH}_{4}$ flux modeled with the countyand polygon-based databases in the Taihu Lake region (Fig. 7). For example, in Wu County the $\mathrm{CH}_{4}$ flux modeled with the polygon-based database database is equivalent to $290 \mathrm{~kg} \mathrm{Cha}^{-1} \mathrm{y}^{-1}$. This is nearly 3.7 times the minimum $\mathrm{CH}_{4}$ emissions generated from the county-based database, and 130 times of the maximum $\mathrm{CH}_{4}$ flux generated from the county-based database due to gleyed soils covering an extensive area in this county. Continuous flooding of gleyed soils can be set using the polygon-based database method, but the water management cannot be set using the countybased database method. This is because the simulation of county-based database cannot differentiate the difference of paddy soil type within a county, water management was usually set according to the conventional practice for the entire region, although different soil type have different water management practices. However, the simulation of polygonbased database can differentiate different water management of paddy soil type respectively. In this study, the water management of gleyed paddy soil, which is in a state of long-term waterflooding, is different from other paddy soil sub-region in the Taihu Lake region. All the gleyed paddy soil polygons were simulated separately by adopting water management of continuous flooding. The average value of the relative deviation for Wu County was as high as $880 \%$. This also showed that smaller soil units or using different soil types would improve simulated $\mathrm{CH}_{4}$ emissions from rice fields in the Taihu Lake region using the DNDC model.

On the basis of the DNDC method, the fraction of clay content is the most sensitive parameter in DNDC affecting $\mathrm{CH}_{4}$ emissions ( $\mathrm{Li}$ et al., 2004). The clay content in the county-based database for Yixing (10\%-53\%), Danyang $(16 \%-53 \%)$, Jiaxing (20\%-56\%), Tongxiang (20\%-52\%), and Minhang (17\%-46\%) vary widely. The $\mathrm{CH}_{4}$ flux modeled with the polygon-based database are nearly $0.7,0.7$, 0.7, 0.9 and 1.0 times that of the minimum, respectively, and are nearly 52, 32, 32, 42 and 34 times that of the maximum $\mathrm{CH}_{4}$ flux generated with the county-based database, respectively. With the county level average $\mathrm{CH}_{4}$ flux as the baseline, the average value of the relative deviation ranged from $30 \%$ to $89 \%$ for those counties. Only eight counties (Jiangyin, Wujin, Jintan, Liyang, Deqing, Linan, Chuansha, and Chongmig) had relatively low deviations. The $\mathrm{CH}_{4}$ flux modeled with the polygon-based database were between 0.5 to 2.0 times the minimum and maximum $\mathrm{CH}_{4}$ flux generated with the county-based database due to low discrepancy of soil properties. This comparison indicates that utilizing more precise soil databases will substantially improve the accuracy 
of the estimates of greenhouse gas emissions obtained with process-based models, such as the DNDC model, at regional scales.

\section{Conclusions}

Quantifying $\mathrm{CH}_{4}$ emissions from wetland ecosystems is a relatively new issue in global climate change studies. Process-based models integrated with GIS databases can play an important role in the biogeochemical cycles based on spatially differentiated information, and either mitigation efforts in the most beneficial regions or evaluate spatial variability of greenhouse gas impacts. The biogeochemical model, DeNitrification and DeComposition or DNDC, is a powerful tool for estimating $\mathrm{CH}_{4}$ emissions from terrestrial ecosystems and has been applied in rice paddies with various purposes. This study showed that by linking with a detailed soil database, the DNDC model estimated emissions equivalent to $5.7 \mathrm{Tg} \mathrm{C}$ from the $2.3 \mathrm{Mha}$ of paddy rice fields in the Taihu Lake region of China for the period between 1982 and 2000. The modeled annual $\mathrm{CH}_{4}$ emissions were highly variable from year to year. The trend is mainly attributed to the increase or decrease of $\mathrm{N}$-fertilizer and livestock manure application.

Annual $\mathrm{CH}_{4}$ emission rates in the Taihu Lake region are highly differentiated based on paddy soil subgroups, subregions, and county levels due to heterogeneity in soil properties. Therefore, uncertainty in soil properties introduces large uncertainty into $\mathrm{CH}_{4}$ estimates. As such, using smaller soil units is preferable for defining implementation of government policies designed to reduce $\mathrm{CH}_{4}$ emissions in the Taihu Lake region. Further, smaller soil units help to ensure that such policies can be implemented at the farm level successfully.

At the regional scale, total $\mathrm{CH}_{4}$ emissions were estimated with the DNDC model by linking it to two different soil databases. The $\mathrm{CH}_{4}$ emissions modeled with the two databases showed similar spatial patterns of $\mathrm{CH}_{4}$ fluxes across the counties. However, discrepancies existed between the results from the two methods due to heterogeneity in soil properties (e.g. clay content). In addition, the simulation of county-based database of the default method with the DNDC model cannot differentiate the difference of paddy soil type within a county, water management was usually set according to the conventional practice for the entire region. However, polygon-based database can simulate different water management of paddy soil type respectively. Therefore, utilizing more precise soil databases will substantially improve the accuracy of the estimates of greenhouse gas emissions from process-based models.

Acknowledgements. We gratefully acknowledge support for this research from National Natural Science Foundation of China (No. 40621001), National Basic Research Program of China (2007CB407206) and The Frontier Project of the Chinese Academy of Sciences (No. ISSASIP0715). The participation of Changsheng $\mathrm{Li}$ in the study was supported by NASA's Interdisciplinary Sciences (IDS) program and NSF's project "Understanding linkages between human and biogeochemical processes in agricultural landscapes".

Edited by: K. Küsel

\section{References}

Cai, Z., Xing. G., Shen, G., Xu, H., Yan, X., Yagi, K., and Minami, K.: Measurements of $\mathrm{CH}_{4}$ and $\mathrm{N}_{2} \mathrm{O}$ emissions from rice paddies in Fengqiu, China, Soil Sci. Plant. Nutr., 45, 1-13, 1999.

Cai, Z., Sawamoto, T., Li, C., Kang, G., Boonjawat, J., Mosier, A., Tsuruta, H., and Wassmann, R.: Field validation of the DNDC model for greenhouse gas emissions in East Asian cropping systems, Global Biogeochem. Cy., 17(4), GB1107, doi:10.1029/2003 GB002046, 2003.

Cai, Z., Xu, H., Zhang, H., and Jin, J.: Estimate of methane emission from rice paddy fields in Taihu Lake Region, China, Pedosphere, 4, 297-306, 1994.

Cai, Z., Yan, X., and Xu, H.: Impact of different types of nitrogen fertilizer on $\mathrm{CH}_{4}$ emission from rice fields, Acta. Pedo. Sin (In Chinese), 32, 136-143, 1995.

Cao, M., Dent, J. B., and Heal, O. W.: Modeling of methane emission from rice paddies, Global Biogeochem. Cy., 9, 183-195, 1995a.

Cao, M., Dent, J. B., and Heal, O. W.: Methane emissions from China's rice paddies, Agric. Ecosyst. Environ., 55, 129-137, 1995 b.

Cao, M., Gregson, K., Marshall, S. J., Dent, J. B., and Heal, O. W.: Global methane from rice paddies, Chemosphere, 33, 879-897, 1996.

Cao, M., Gregson, K., and Marshall, S.: Global methane emission from wetlands and its sensitivity to climate change, Atmos. Environ., 32, 3293-3299, 1998.

Cicerone, R. J. and Oremland, R. S.: Biogeochemical aspects of atmospheric methane, Global Biogeochem. Cycles, 2, 299-327, 1988.

Denier van der Gon, H. A. C. and Neue, H. U.: Impact of gypsum application on the methane emission from a wetland rice field, Global Biogeochem. Cy., 8, 127-134, 1994.

Dunfield, P. F., Topp, E., Archambault, C., and Knowles, R.: Effect of nitrogen fertilizers and moisture content on $\mathrm{CH}_{4}$ and $\mathrm{N}_{2} \mathrm{O}$ fluxes in a humisol: Measurements in the field and intact soil cores, Biogeochemistry, 29, 199-222, 1995.

Huang, Y., Sass, R. L., and Fisher, F. M.: A semi-empirical model of methane emission from flooded rice paddy soils, Global Change. Biol., 4, 247-268, 1998.

IPCC-Intergovemmental panel on climate change: Climate change 1995: The Science of Climate Change, Cambridge University Press, Cambridge, UK, 1996.

IPCC-Intergovemmental panel on climate change: Changes in Atmospheric Constituents and in Radiative Forcing, in: IPCC Fourthly Assessment Report, 141-142, 2007.

Jagadeesh Babu, Y., Li, C., Frolking, S., Nayak, D. R., and Adhya, T. K.: Field validation of DNDC model for methane and nitrous oxide emissions from rice-based production systems of India, Nutr. Cy. Agroecosyst., 74, 157-174, 2006. 
Jiang, C., Wang, Y., Zheng, X., and Wang, M.: Advances in the research on methane emission from paddy fields and its affecting factors, Chin. J. Soil. Sci. (in Chinese), 35, 663-669, 2004.

Lelieveld, J., Crutzen, P. J., and Brühl, C.: Climate effects of atmospheric methane, Chemosphere, 26, 739-768, 1993.

Li, C.: Modeling trace gas emissions from agricultural ecosystems, Nutr. Cy. Agroecosyst., 58, 259-276, 2000.

Li, C.: Quantifying greenhouse gas emissions from soils: Scientific basis and modeling approach, Soil Sci. Plant. Nutr., 53, 344-352, 2007.

Li, C., Mosier, A., Wassmann, R., Cai, Z., Zheng, X., Huang, Y., Tsuruta, H., Boonjawat, J., and Lantin, R.: Modeling greenhouse gas emissions from rice-based production systems: Sensitivity and upscaling, Global Biogeochem. Cy., 18(1), GB1043, doi:10.1029/2003GB002045, 2004.

Li, C., Frolking, S., and Frolking, T. A.: A model of nitrous oxide evolution from soil driven by rainfall events: I. Model structure and sensitivity, J. Geophys. Res., 97(D9), 9759-9776, 1992a.

Li, C., Frolking, S., and Frolking, T. A.: A model of nitrous oxide evolution from soil driven by rainfall events: II. Model applications, J. Geophys. Res., 97(D9), 9777-9783, 1992b.

Li, C., Frolking, S., and Harriss, R.: Modeling carbon biogeochemistry in agricultural soils, Global Biogeochem. Cy., 8, 237-254, 1994.

Li, C., Qiu, J., Frolking, S., Xiao, X., Salas, W., Moore III, B., Boles, S., Huang, Y., and Sass, R.: Reduced methane emissions from large-scale changes in water management in China's rice paddies during 1980-2000, Geophys. Res. Lett., 29(20), GB1972, doi:10.1029/2002GL015370, 2002.

Li, C., Narayanan, V., and Harriss, R.: Model estimates of nitrous oxide emissions from agricultural lands in the United States, Global Biogeochem. Cy., 10, 297-306, 1996.

Li, C., Salas, W., DeAngelo, B., and Rose, S.: Assessing alternatives for mitigating net greenhouse gas emissions and increasing yields from rice production in China over the next twenty years. J. Environ. Qual., 35, 1554-1565, 2006.

Li, D., Zhang, J., Li, W., Yue, Z., Yu, F., and Gu, J.: Influence of different agricultural measure on $\mathrm{CH}_{4}$ emissions, J. Ecol. Rural. Environ. (In Chinese), (S1), 13-27, 1993.

Li, Q., (ed.): Paddy soil in China, China Science Press (In Chinese), 72-80, 1992.

Lindau, C. W., DeLaune, R. D., Patrick Jr., W. H., and Bollich, P. K.: Fertilizer effects on dinitrogen, nitrous oxide and methane emission from lowland rice, Soil Sci. Soc. Am. J., 54, 17891794, 1990.

Ma, Y. and Chen, J.: Change in Paddy soil Materials and Effect on Eco-environment, China Science Press (In Chinese), 123-129, 1999.

Matthews, R. B., Wassmann, R., and Arah, J.: Using a crop/soil simulation model and GIS techniques to assess methane emissions from rice fields in Asia: I. Model development, Nutr. Cy. Argoecosyst., 58, 141-159, 2000a.

Matthews, R. B., Wassmann, R., Knox, J. W., and Buendia, L. V.: Using a crop/soil simulation model and GIS techniques to assess methane emissions from rice fields in Asia: IV. Upscaling to national levels, Nutr. Cy. Argoecosyst., 58, 201-217, 2000 b.

Pacey, J. G. and DeGier, J. P.: The factors influencing land fill gas production. In: Energy from landfill gas, Proceeding of a conference jointly sponsored by the United Kingdom Department of Energy and the United States Department of Energy (October 1986), 51-59, 1986.

Pathak, H., Li, C., and Wassmann, R.: Greenhouse gas emissions from Indian rice fields: calibration and upscaling using the DNDC model, Biogeosciences, 2, 113-123, 2005,

http://www.biogeosciences.net/2/113/2005/.

Qiu, J., Wang, L., Tang, H., Li, H., and Li, C.: Studies on the situation of soil organic carbon storage in croplands in northeast of China, Chin. Agric. Sci. (in Chinese), 37 (8), 1166-1171, 2004.

Rashid, A., Khan, R. U., and Ullah, H.: Influence of nitrogen levels and application methods on yield and quality of sorghum, Pedosphere, 18(2), 236-241, 2008.

Rüth, B. and Lennartz, B.: Spatial variability of soil properties and rice yield along two catenas in southeast China, Pedosphere, 18(4), 409-420, 2008.

Sass, R. L., Fisher, F. M., Wang, Y., Turner, F. T., and Jund, M. F.: Methane emission from rice fields as influenced by solar radiation, temperature, and straw incorporation, Global Biogeochem. Cy., 5, 335-350, 1991.

Shi, X., Yu, D., Warner, E. D., Pan, X., Petersen, G. W., Gong, Z. G., and Weindorf, D. C.: Soil database of 1:1,000,000 digital soil survey and reference system of the Chinese Genetic Soil Classification System, Soil Surv. Horizons., 45(4), 129-136, 2004.

Shi, X., Yu, D., Warner, E. D., Sun, W., Petersen, G. W., Gong, Z., and Lin, H.: Cross-reference system for translating between genetic soil classification of China and Soil Taxonomy, Soil Sci. Soc. Am. J., 70, 78-83, 2006.

Soil Survey Staff (Eds.).: Keys to soil taxonomy, US Gov. Print Office, Washington, DC, USA, 6th ed., 437 pp., 1994.

Sun, B., Shen, R., and Bouwman, A. F.: Surface N balances in agricultural crop production systems in China for the period 19802015, Pedosphere, 18(3), 304-315, 2008.

Tang, H., Qiu, J., Ranst, E. V., and Li, C.: Estimations of soil organic carbon storage in cropland of China based on DNDC model, Geoderma, 134, 200-206, 2006.

Wang, M., Dai, A., Huang, J., Ren, L., Shen, R., Schutz, H., Rennenberg, H., Seiler, W., Rasmussen, R. A., and Khalil, M. A. K.: Sources of methane in China: rice fields, agricultural waste treatment, cattle, coal mines, and other minor sources, Sci. Atmos. Sin. (in Chinese), 17, 52-64, 1993.

Wang, X., Ouyang, Z., and Miao, H.: Application of DNDC Model in Estimation of $\mathrm{CH}_{4}$ and $\mathrm{N}_{2} \mathrm{O}$ Emissions in Agricultural Ecosystems in Yangtze River Delta, Environ. Sci. (In Chinese), 22(3), 15-19, 2001.

Wang, Z., DeLaune, R. D., Patrick Jr., W. H., and Masscheleyn, P. H.: Soil redox and $\mathrm{pH}$ effects on methane production in a flooded rice soil, Soil Sci. Soc. Am. J., 57, 382-385, 1993.

Wassmann, R., Neue, H. U., Lantin, R. S., Aduna, J. B., Alberto, M. C. R., Andales, M. J., Tan, M. J., Denier van der Gon, H. A. C., Hoffmann, H., Papen, H., Rennenberg, H., and Seiler, W.: Temporal patterns of methane emissions from wetland rice fields treated by different modes of $\mathrm{N}$ application, J. Geophys. Res., 99(D8), 16457-16462, 1994.

Xiong, X., Shen, R., Wang, M., Zheng, X., Wang, Y., and Li, J.: Methane emission from rice paddy field of Ta-Lake area, Chin. J. Atmosc. Sci. (In Chinese), 23(1), 9-18, 1999.

Xu. Q., Lu, Y., Liu, Y., and Zhu, H.: Paddy soil of Taihu Lake region in China, China Science Press (In Chinese), 37-40, 1980.

Yagi, K., Minami, K.: Effect of organic matter applications on 
methane emission from some Japanese paddy fields, Soil Sci. Plant Nutr., 36, 599-610, 1990.

Yao, H. and Chen, Z.: Effect of chemical fertilizer on methane emission from rice paddies, J. Geophys. Res., 99(D8), 16463-16470, 1994.

Yao, H., Conrad, R., Wassmann, R., and Neue, H. U.: Effect of soil characteristics on sequential reduction and methane production in sixteen rice paddy soils from China, the Philippines, and Italy, Biogeochemistry, 47(3), 267-293, 1999.

Yu, K., William H., and Patrick Jr.: Redox window with minimum global warming potential contribution from rice soils, Soil Sci. Soc. Am. J., 68, 2086-2091, 2004.
Yu, K., Wang, Z., Vermoesen, A., Patrick Jr., W., and Van Cleemput, O.: Nitrous oxide and methane emissions from different soils suspensions: effect of soil redox status, Biol. Fertil. Soil., 34, 25-30, 2001.

Zheng, X., Wang, M., Wang, Y., Shen, R., Shangguan, X., Heyer, J., Kogge, M., Papen, H., Jin, J., and Li, L.: $\mathrm{CH}_{4}$ and $\mathrm{N}_{2} \mathrm{O}$ emissions from rice paddies in southeast China, Chin. J. Atmos. Sci., 21, 167-174, 1997.

Zheng, X., Wang, M., Wang, Y., Shen, R., Shangguan, X., Heyer, J., KÖgge, M., Papen, H., Jin, J., and Li, L.: Characters of greenhouse gas $\left(\mathrm{CH}_{4}, \mathrm{~N}_{2} \mathrm{O}, \mathrm{NO}\right)$ emissions from croplands of southeast China, World Resour. Review, 11(2), 229-246, 1999. 